\title{
S-100B Concentrations Predict Disease-Free Survival in Stage III Melanoma Patients
}

\author{
S. Kruijff, MD' ${ }^{1}$ E. Bastiaannet, $\mathrm{MSc}^{1}$, A. C. Muller Kobold, MSc, $\mathrm{PhD}^{2}$, R. J. van Ginkel, MD, $\mathrm{PhD}^{1}$, \\ A. J. H. Suurmeijer, MD, $\mathbf{P h D}^{3}$, and $\mathrm{H}$. J. Hoekstra, MD, $\mathbf{P h D}^{1}$ \\ ${ }^{1}$ Division of Surgical Oncology, University Medical Centre Groningen, University of Groningen, Groningen, The \\ Netherlands; ${ }^{2}$ Department of Laboratory Medicine, University Medical Centre Groningen, University of Groningen, \\ Groningen, The Netherlands; ${ }^{3}$ Department of Pathology, University Medical Centre Groningen, University of Groningen, \\ Groningen, The Netherlands
}

\begin{abstract}
Background. Elevation of the tumor marker S-100B in melanoma patients is a highly specific indicator of recurrence.

Materials and methods. The role of S-100B in diseasefree survival (DFS) was evaluated in stage III melanoma patients (staged with fluorodeoxyglucose positron emission tomography [FDG-PET] and computed tomography [CT]) with palpable lymph node metastases who underwent therapeutic lymph node dissection. S-100B and LDH were measured on the day before surgery $(d=-1)$ and on days 1,2 , and 7 postoperatively. Multivariate logistic regression was used to study factors associated with preoperative elevation of S-100B. Univariate (log-rank test) and multivariate (Cox regression) survival analyses were performed to identify factors associated with DFS.

Results. Between 2004 and 2008, 56 patients (median age 57, range 24-93) years, 27 males (48\%) and 29 females (52\%) entered the study. Preoperative S-100B elevation was found in 27 patients (48\%) and elevated LDH in 20 patients $(36 \%)$. No association was found between these two markers at any time. Multivariate analysis showed that elevated S-100B preoperatively (hazard ratio [HR] 2.7, $P=.03$ ) was associated with DFS. S-100B elevation was
\end{abstract}

Presented at the 14th Congress of the European Society of Surgical Oncology, The Hague, The Netherlands, September 10-12, 2008.

(C) The Author(s) 2009. This article is published with open access at Springerlink.com

First Received: 8 October 2008;

Published Online: 28 July 2009

H. J. Hoekstra, MD, PhD

e-mail: h.j.hoekstra@chir.umcg.nl associated with increased tumor size (odds ratio [OR] 3.40; $P=.03$ ).

Conclusion. Elevated S-100B preoperatively in patients with optimally staged clinical stage III melanoma is associated with decreased disease-free survival. S100-B could be used as a prognostic marker in the stratification of new adjuvant trials to select stage III melanoma patients for adjuvant systematic treatment.

The incidence of melanoma is still increasing in the Netherlands. Between 1989 and 2003, the incidence increased from 9.5 to $13.7 / 100,000$ in men and from 13.4 to 18.5/100,000 in women. ${ }^{1}$ About $90 \%$ of the patients had stage I or II melanoma. ${ }^{2}$ After surgical treatment, 20-28\% of melanoma patients present with locoregional recurrence or regional dermal metastases, 26-60\% with regional recurrences, and $15-50 \%$ with distant metastases. ${ }^{3}$ Despite improved public awareness as well as early diagnosis and treatment, mortality from melanoma increased from 2.5 to $3.6 / 100,000$ in men and from 2.0 to $2.4 / 100,000$ in women in the Netherlands between 1989 and $2003 .{ }^{1}$

It is impossible to predict the metastatic behavior of melanoma in individual patients. At present, the Multicentre Selective Lymphadenectomy Trial (MSLT II) is investigating whether sentinel lymph node biopsy reduces the risk of locoregional metastases and improves survival. ${ }^{4}$ In patients with clinical stage III melanoma (palpable lymph node metastases), 5-year survival varied between 26 and $67 \% .^{5}$ Recent staging studies with whole-body fluorodeoxyglucose positron emission tomography (FDG-PET) and/ or spiral computed tomography (CT) in patients with clinical stage III melanoma have shown that about one quarter of these patients had distant metastases. ${ }^{6,7}$ Furthermore, the uptake of FDG in the lymph node metastases in patients with 
clinical stage III melanoma proved to be of prognostic value. $^{8}$ FDG-PET or spiral CT improved the staging of clinical stage III melanoma and led to better selection of patients for therapeutic lymph node dissection. ${ }^{6,7}$

Serum lactate dehydrogenase (LDH) had high specificity for melanoma, but low sensitivity. It was an independent prognostic factor in stage IV melanoma. ${ }^{9-12}$ Increased S-100B concentrations were first detected in melanoma patients in $1980 .{ }^{13}$ Later, S-100B was found to be a serological tumor marker for melanoma and is mostly increased in stage III and IV. ${ }^{14,15}$

$\mathrm{S}-100 \mathrm{~B}$ is a 21 kilodalton $(\mathrm{kDa})$ protein that was first isolated from the central nervous system in vertebrates. The name is derived from its $100 \%$ solvency in saturated ammonium sulfate with neutral $\mathrm{pH}$. It has calcium-binding properties and as a dimer, consists of two isomers $\alpha$ and $\beta$. All possible combinations can occur (S-100 $\alpha \alpha, \mathrm{S}-100 \alpha \beta$, S$100 \beta \beta) .{ }^{15}$ The S-100B protein is of neuroectodermal and mesodermal origin and is expressed in various parts of the body. S-100B is chiefly found in glial cells and Schwann cells. ${ }^{16}$ Serum S-100B can be measured with an immunoradiometric assay (Sangtec 100 IRMA/RIA assay) or with an immunoluminometric assay (LIA Mat Sangtec 100).

This study addressed the question whether the perioperative measurement of the tumor markers S-100B has prognostic value in FDG-PET and spiral CT staged patients with stage III melanoma who are selected for therapeutic lymph node dissection.

\section{MATERIALS AND METHODS}

\section{Patients}

Melanoma patients, earlier staged AJCC I and II, now presenting with clinically and cytologically proven regional nodal metastases of melanoma (AJCC stage IIIb and IIIc) were staged with whole-body FDG-PET (Siemens ECAT EXACT HR + scanner) and with 64-slice spiral CT (Siemens Somatom Sensation). Sentinel node positive patients and patients with regional dermal metastases were excluded for this study. The patients whose test results were negative for distant metastases were eligible for therapeutic lymph node dissection with curative intent. Nodal metastases of $\geq 3 \mathrm{~cm}$ and/or $\geq 3$ positive lymph nodes and/or extra nodal growth received adjuvant radiotherapy $(20 \times 2.4$ Gy). ${ }^{17,18} \mathrm{LDH}$ and S-100B were measured preoperative (day -1 ) and postoperative days 1,2 , and 7 . The study was approved by the Medical Ethical Committee of the UMCG.

\section{Methods}

LDH was analyzed routinely by means of Roche Modular (Hitachi) with an enzymatic activity measurement; normal values of LDH were considered to be $<250 \mathrm{U} / \mathrm{L}$. Concentrations of S-100B were measured using Sangtec 100 immunoassay on the Advantage (Nichols).

The S-100B half-life is estimated to be $30 \mathrm{~min}^{19}$ Approximately 10 times the half-life after lymph node dissection, S-100B values should reduce to the minimum possible. When tumor cells are still present the release of S-100B will continue or may even increase. Therefore, S-100B levels were measured on days $-1,1,2$, and 7 .

Levels were calculated on the basis of a calibration curve and checked against internal standards with a known concentration of S-100B. In this assay, a cut-off point of $0.15 \mathrm{~g} / \mathrm{L}$ was set. The reference values for the S-100B assay (Liason Sangtec 100) were established by analysis of S-100B values of 120 healthy men and women according to the CLSI C28A2 guideline. Concentrations within this range were considered to be normal, whereas concentration above this range were considered to be elevated. A postoperative increase of S-100B was defined as any increase on the postoperative days 1,2 , or 7 (day 1 as baseline value, elevation on day 2 compared with day 1 , and/ or elevation on day 7 compared with day 2 ).

\section{Statistics}

Data were analyzed with STATA version 10.0. Logistic regression analysis was used to assess factors associated with elevated S-100B concentrations. Factors associated with disease-free survival (DFS) were analyzed with standard univariate (log-rank test) and multivariate (Cox proportions hazard) survival methods.

\section{RESULTS}

\section{Patients}

In the period from January 2004 to January 2008, 56 patients (27 males [48\%] and 29 females [52\%]), median age 57 (range 24-93) years underwent therapeutic lymph node dissection (Table 1). Preoperatively, 27 patients had elevated S-100B concentrations (48\%), while 20 patients had increased LDH levels (36\%). The range on day $-1,1$, 2 , and 7 for S-100B was $0.03-23.3,0.02-1.5,0.03-0.82$, $0.01-0.22$ and for LDH 109-428, 106-816, 108-335, 115802. No associations were found between S-100B and LDH levels on days $-1,1,2$, and $7(P=.45, P=.87, P=.84$, and $P=.90$, respectively). The S-100B concentration normalized postoperatively in 22 of the 27 patients $(81.4 \%)$ and the LDH in 18 of the 20 patients $(90 \%)$.

Preoperative S-100B elevation was associated with increased lymph node size (odds ratio [OR] 3.4, $P=.03$ ), however not significantly with extranodal growth $(P=.8)$, 
TABLE 1 Characteristics of 56 AJCC stage III melanoma patients

\begin{tabular}{|c|c|c|}
\hline Variable & Patients & Percentage \\
\hline \multicolumn{3}{|l|}{ Gender } \\
\hline Male & 27 & 48.2 \\
\hline Female & 29 & 51.8 \\
\hline Median age (years) & 57.0 & \\
\hline \multicolumn{3}{|c|}{ Localization primary tumor } \\
\hline Trunk & 24 & 42.8 \\
\hline Head and neck & 3 & 5.3 \\
\hline Upper extremities & 7 & 12.5 \\
\hline Lower extremities & 22 & 55.8 \\
\hline \multicolumn{3}{|c|}{ Breslow thickness primary tumor } \\
\hline $\mathrm{T} 1(<1.0 \mathrm{~mm})$ & 7 & 12.5 \\
\hline $\mathrm{T} 2(1.0-2.0 \mathrm{~mm})$ & 20 & 35.7 \\
\hline T3 $(2.0-4.0 \mathrm{~mm})$ & 21 & 37.5 \\
\hline $\mathrm{T} 4(>4.0 \mathrm{~mm})$ & 8 & 14.2 \\
\hline \multicolumn{3}{|c|}{ Clark level primary tumor } \\
\hline $1-3$ & 24 & 42.6 \\
\hline $4-5$ & 31 & 55.4 \\
\hline Unknown & 1 & 1.8 \\
\hline \multicolumn{3}{|c|}{ Localization lymph nodes } \\
\hline Neck & 6 & 10.7 \\
\hline Axilla & 20 & 35.7 \\
\hline Groin & 30 & 53.5 \\
\hline \multicolumn{3}{|l|}{ Nodes removed } \\
\hline$<15$ & 27 & 48.2 \\
\hline$\geq 15$ & 29 & 52.8 \\
\hline \multicolumn{3}{|l|}{ Positive nodes } \\
\hline$<2$ & 36 & 64.3 \\
\hline$\geq 2$ & 20 & 35.7 \\
\hline \multicolumn{3}{|l|}{ Extranodal growth } \\
\hline Yes & 24 & 42.6 \\
\hline No & 42 & 56.4 \\
\hline \multicolumn{3}{|l|}{ Lymph node size } \\
\hline$<3 \mathrm{~cm}$ & 28 & 50.0 \\
\hline$\geq 3 \mathrm{~cm}$ & 28 & 50.0 \\
\hline \multicolumn{3}{|c|}{ Ulceration primary tumor } \\
\hline Yes & 13 & 23.2 \\
\hline No & 43 & 76.8 \\
\hline \multicolumn{3}{|l|}{ AJCC stage } \\
\hline IIIa & 0 & 0.0 \\
\hline IIIb & 30 & 53.6 \\
\hline IIIIc & 26 & 46.4 \\
\hline
\end{tabular}

more than 2 positive lymph nodes $(P=.5)$, age $(P=.6)$, or gender $(P=.6)$ (Table 2).

\section{Disease-Free Survival}

During a median follow-up of 14.2 months (range 0.640.9) months, tumor recurrence was diagnosed in 24
TABLE 2 Logistic regression analysis on elevated preoperative S100B in stage III melanoma patients

\begin{tabular}{|c|c|c|c|}
\hline Variable & $\begin{array}{l}\text { Elevated preoperative } \\
\text { S-100B }(\%)\end{array}$ & OR & $P$ value \\
\hline \multicolumn{4}{|l|}{ Sex } \\
\hline Male & 51.9 & Ref & \\
\hline Female & 44.8 & $0.8(0.3-2.2)$ & .6 \\
\hline \multicolumn{4}{|l|}{ Age } \\
\hline$<55$ years & 44.0 & Ref & \\
\hline$\geq 55$ years & 51.6 & $1.4(0.5-3.9)$ & .6 \\
\hline \multicolumn{4}{|c|}{ Positive lymph nodes } \\
\hline$\leq 2$ & 44.4 & Ref & \\
\hline$>2$ & 55.0 & $1.5(0.5-4.6)$ & .5 \\
\hline \multicolumn{4}{|c|}{ Extranodal growth } \\
\hline Yes & 52.2 & Ref & \\
\hline No & 48.4 & $0.9(0.3-2.5)$ & .8 \\
\hline \multicolumn{4}{|l|}{ Tumor size } \\
\hline$<3 \mathrm{~cm}$ & 35.7 & Ref & \\
\hline$\geq 3 \mathrm{~cm}$ & 65.4 & $3.4(1.1-10.4)$ & .03 \\
\hline
\end{tabular}

Elevated S-100B was defined as S-100B $\geq 0.15 \mathrm{~g} / \mathrm{L}$

Ref reference category

patients (43\%), of which 17 patients were diagnosed with distant metastasis and 7 patients with a regional recurrence. As shown in Table 3, DFS was not associated with sex, localization of the lymph node, or the size of the lymph nodes. Two-year DFS in patients with elevated preoperative S-100B concentrations was $34 \%$ versus $61 \%$ for patients without elevated preoperative S-100B concentrations (hazard ratio $[\mathrm{HR}] 2.6, P=.03$ ). In the patients whose S-100B increased postoperatively, 2-year DFS was $30 \%$ versus $51 \%$ for patients without a postoperative S100B increase (HR 2.0, $P=.1$ ) (Fig. 1).

In multivariate analysis (model with positive lymph nodes, extranodal growth, preoperative and postoperative S-100B and substage IIIb or IIIc), extranodal growth (HR $0.4, P=.05$ ), and elevated preoperative S-100B concentrations (HR 2.6, $P=.03$ ) were significantly associated with decreased DFS. Patients with increasing postoperative S-100B serum levels showed a trend toward statistical significance when correlated to DFS (HR 2.6, $P=.07$ ).

\section{DISCUSSION}

This is the first study that demonstrates a potential prognostic value of preoperative S-100B concentrations in patients who underwent a therapeutic lymph node dissection after preoperative staging with FDG-PET and CT. According to the literature, the proportions of patients with elevated S-100B concentrations were $0-9 \%$ in stage I/II, 
TABLE 3 Disease-free survival (DFS) of AJCC stage III melanoma patients
Ref reference category

FIG. 1 Kaplan-Meier curve for preoperative S-100B and disease-free survival of AJCC stage III melanoma patients. a Elevated preoperative S-100B (34\% 2-year DFS) versus not elevated (61\% 2-year DFS) levels are associated with a decreased disease-free survival $(P=.03)$. b Increasing postoperative S-100B levels (30\% 2-year DFS) versus not increasing (51\% 2-year DFS) $(P=.1)$

\begin{tabular}{|c|c|c|c|c|c|}
\hline \multirow[t]{2}{*}{ Variable } & \multirow[t]{2}{*}{ 2-year DFS (\%) } & \multicolumn{2}{|c|}{ Univariate analysis } & \multicolumn{2}{|c|}{ Multivariate analysis } \\
\hline & & HR $(95 \%$ CI $)$ & $P$ value & HR $(95 \%$ CI $)$ & $P$ value \\
\hline \multicolumn{6}{|l|}{ Sex } \\
\hline Male & 45 & Ref & & & \\
\hline Female & 47 & $1.2(0.5-2.6)$ & .7 & & \\
\hline \multicolumn{6}{|c|}{ Localization lymph node } \\
\hline Neck & 83 & Ref & & & \\
\hline Axilla & 51 & $3.3(0.4-26)$ & & & \\
\hline Groin & 36 & $4.9(0.7-37)$ & .2 & & \\
\hline \multicolumn{6}{|c|}{ Positive lymph nodes } \\
\hline$\leq 2$ & 64 & Ref & & Ref & \\
\hline$>2$ & 23 & $3.3(1.5-7.5)$ & .004 & $1.6(0.6-4.3)$ & .3 \\
\hline \multicolumn{6}{|c|}{ Extranodal growth } \\
\hline Yes & 28 & Ref & & Ref & \\
\hline No & 58 & $0.4(0.2-0.8)$ & .02 & $0.4(0.1-1.0)$ & .05 \\
\hline \multicolumn{6}{|c|}{ Lymph node size $(\mathrm{cm})$} \\
\hline$<3$ & 53 & Ref & & & \\
\hline$\geq 3$ & 35 & $1.5(0.7-3.3)$ & .4 & & \\
\hline \multicolumn{6}{|l|}{ Stage } \\
\hline IIIB & 69 & Ref & & Ref & \\
\hline IIIC & 23 & $3.9(1.6-9.5)$ & .003 & $1.8(0.6-5.2)$ & .3 \\
\hline \multicolumn{6}{|c|}{ Preoperative S-100B } \\
\hline Normal & 61 & Ref & & Ref & \\
\hline Elevated & 34 & $2.6(1.1-6.0)$ & .03 & $2.6(1.1-6.1)$ & .03 \\
\hline \multicolumn{6}{|c|}{ Postoperative $S-100 B$} \\
\hline No increase & 51 & Ref & & Ref & \\
\hline Increase & 30 & $2.0(0.8-4.8)$ & .1 & $2.6(0.9-7.2)$ & .07 \\
\hline
\end{tabular}

(a)

Disease-Free

Survival

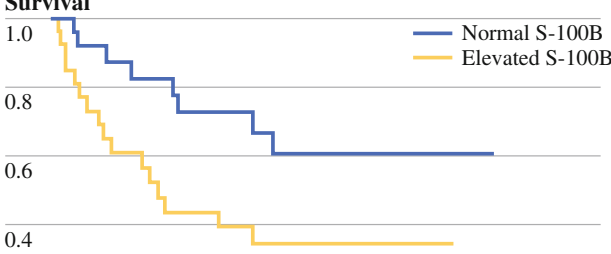

0.2 (b)

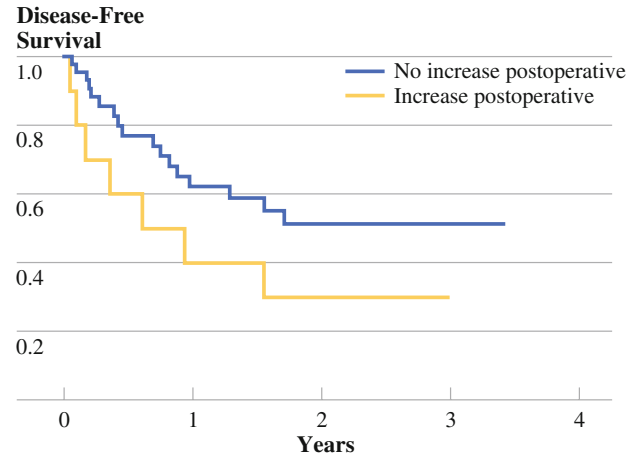

5-98\% in stage III, and 40-100\% in stage IV melanoma (Table 4). The highest S-100B concentrations were found in patients with liver and/or skeletal metastases. ${ }^{20,21}$ Serum S-100B concentrations are therefore correlated with the clinical stage of the disease.

The aim of this study was to evaluate the prognostic value of preoperative and postoperative concentrations of the tumor marker S-100B in clinically stage III melanoma patients who underwent a so-called "curative lymph node dissection" after preoperative staging with whole-body FDG-PET and spiral CT. Our results showed that preoperative elevated concentrations of S-100B was statistically significantly associated with a decreased DFS. It is difficult to compare the studies investigating the value of S-100B in patients with melanoma, because various assays (IRMA or LIA-mat) and cut-off points and groups of patients with different stages were used (Table 4). ${ }^{8}$ Garbe et al. also found a relation between $\mathrm{S}-100 \mathrm{~B}$ and disease-free survival 
TABLE 4 Review literature S-100B values above cut-off point in melanoma patients

\begin{tabular}{|c|c|c|c|c|c|c|}
\hline Reference & No. & Assay & Cut-off value & Stage I/II & Stage III & Stage IV \\
\hline Guo et al. ${ }^{14}$ & 126 & IRMA & 0.15 & $1 \%$ & $9 \%$ & $74 \%$ \\
\hline Miliotes et al. ${ }^{38}$ & 67 & IRMA & 0.05 & $47.8 \%$ & - & - \\
\hline Abraha et al. ${ }^{39}$ & 97 & IRMA & 0.2 & $9 \%$ & $82 \%$ & - \\
\hline Bosserhoff et al. ${ }^{40}$ & 112 & IRMA & 0.15 & $0 \%$ & $62 \%$ & - \\
\hline Buer et al. ${ }^{24}$ & 99 & IRMA & 3.00 & - & - & $22.2 \%$ \\
\hline Henze et al. ${ }^{29}$ & 73 & IRMA & 0.3 & $4 \%$ & $21 \%$ & $79 \%$ \\
\hline Tofani et al. ${ }^{41}$ & 53 & IRMA & 0.5 & $0 \%$ & $55 \%$ & - \\
\hline Schultz et al. ${ }^{42}$ & 84 & IRMA & 0.3 & $0 \%$ & $31 \%$ & $69 \%$ \\
\hline Bonfrer et al. ${ }^{43}$ & 251 & LIA & 0.16 & I/II: $1 \%$ & - & III/IV: 79\% \\
\hline Seregni et al. ${ }^{44}$ & 438 & IRMA & 0.2 & I: $4.2 \%$, II: $5.3 \%$ & $38.5 \%$ & - \\
\hline Hauschild et al. ${ }^{45}$ & 412 & IRMA & 0.2 & $2 \%$ & $19 \%$ & $68 \%$ \\
\hline Curry et al. ${ }^{22}$ & 147 & IRMA/LIA & $0.2 / 0.12$ & - & $23 \% / 47.5 \%$ & - \\
\hline Berking et al. ${ }^{46}$ & 352 & LIA & 0.2 & $7 \%$ & $8 \%$ & $48 \%$ \\
\hline Jackel et al. ${ }^{16}$ & 276 & LIA & 0.12 & $6 \%$ & $5 \%$ & $48 \%$ \\
\hline Kaskel et al. ${ }^{47}$ & 570 & LIA & 0.11 & $9 \%$ & $94 \%$ & - \\
\hline Brouard et al. ${ }^{48}$ & 122 & LIA & 0.09 & $0 \%$ & $54 \%$ & $84 \%$ \\
\hline Vuoristo et al. ${ }^{49}$ & 50 & LIA & 0.12 & - & - & $64.0 \%$ \\
\hline Jury et al. ${ }^{50}$ & 214 & LIA & 0.2 & $7 \%$ & $29 \%$ & $92 \%$ \\
\hline Mohammed et al. ${ }^{21}$ & 68 & LIA & 0.2 & - & - & $73.5 \%$ \\
\hline Martenson et al..$^{20}$ & 727 & LIA & 0.10 & $12 \%$ & - & III/IV: $72 \%$ \\
\hline Juergensen et al. ${ }^{51}$ & 50 & LIA & 0.12 & - & - & I/II/III/IV: $50 \%$ \\
\hline Rebmann et al. ${ }^{52}$ & 183 & LIA & 0.12 & - & - & I/II/III/IV: $21 \%$ \\
\hline Banfalvi et al. ${ }^{30}$ & 59 & LIA & 0.12 & $40 \%$ & $25 \%$ & $59 \%$ \\
\hline Garbe et al. ${ }^{32}$ & 296 & LIA & 0.12 & & & \\
\hline Banfalvi et al. ${ }^{31}$ & 478 & LIA & 0.18 & I: $29 \%$, II: $19 \%$ & $32 \%$ & $48 \%$ \\
\hline Andres et al. ${ }^{53}$ & 85 & LIA & 0.15 & - & I/II/III: $15 \%$ & $89 \%$ \\
\hline Ugurel et al. ${ }^{54}$ & 300 & LIA & 0.12 & - & - & I/II/III/IV: $20 \%$ \\
\hline Smit et al. ${ }^{15}$ & 145 & LIA & 0.16 & - & - & $78 \%$ \\
\hline Schmidt et al. ${ }^{55}$ & 85 & LIA & 0.15 & - & - & $59 \%$ \\
\hline Domingo et al. ${ }^{33}$ & 97 & LIA & 0.15 & - & II/III: $21 \%$ & - \\
\hline Cao et al. ${ }^{56}$ & 42 & LIA & 0.20 & - & - & $50 \%$ \\
\hline Tarhini et al. ${ }^{37}$ & 670 & LIA & 0.15 & - & IIb/III: $13 \%$ & - \\
\hline Kruijff et al. 2009 & 56 & LIA & 0.15 & - & $48 \%$ & - \\
\hline
\end{tabular}

LIA lumino immunometric assay, IRMA immuno radiometric assay

in stage II and III melanoma patients. Postoperative elevated S-100B preceded detection of developing metastases by imaging techniques. ${ }^{2}$ According to Martenson et al. and Curry et al., elevated S-100B in stage III melanoma after lymph node dissection may form an independent prognostic factor. ${ }^{20,22}$ Four studies demonstrated that elevated S-100B was associated with shortened (disease-free) survival. $^{20,23-25}$ In stage IV patients with normal S-100B levels, survival was better for patients with low S-100B levels compared with those with elevated S-100B levels. ${ }^{15,26}$ Increasing concentrations of S-100B in stage IV patients who were receiving systemic treatment were associated with disease progression. ${ }^{14,27-29}$ In a study on
1007 melanoma patients, S-100B was not only correlated with the clinical stage of the disease, but it also appeared to be an independent prognostic marker in stages II and III. The 5-year survival of patients with $\mathrm{S}-100 \mathrm{~B}$ values of $<0.10 \mathrm{~g} / \mathrm{L}$ was $91 \%$, compared with $51 \%$ when the values were $>0.10 \mathrm{~g} / \mathrm{L} .{ }^{20}$ In two other studies, similar patterns were found. ${ }^{30,31}$ Two studies comparing 5-S-cysteinyldopa, LDH and S-100B as prognostic markers found that S-100B had the highest specificity. ${ }^{30,31}$

Several studies have therefore recommended the use of S-100B as a tumor marker to monitor the course of disease in stage III melanoma patients and to evaluate the effect of therapy in stage IV patients. Successful treatment with 
lymph node dissection, chemotherapy, or immunotherapy was associated with decreased S-100B concentrations, whereas increased concentrations were an expression of disease progression. ${ }^{14,27,28}$

The prognostic value of the preoperative and postoperative course of S-100B concentrations in "true stage III" melanoma patients has not been studied before. In advance, we hypothesized that a significant decrease in S-100B concentration after therapeutic lymph node dissection would correlate with better DFS. In this way we assumed S-100B could be used as a quality-control marker for dissection. In our study, 27 patients (48.2\%) had elevated S-100B preoperatively, and indeed in 22 of them $(81.4 \%)$ the concentrations normalized postoperatively. However, 12 patients of these $22(55 \%)$ developed tumor recurrence during a median follow-up of 1.18 years. Multivariate analyses showed that preoperative S-100B elevation was an important predictor of decreased DFS $(P=.03)$.

Although the results indicated that therapeutic lymph node dissection did have a temporary influence on the postoperative course of S-100B, a more important predictor for shortened DFS seemed preoperative S-100B elevation. For AJCC stage III, postoperative increasing S-100B serum were associated with a decreased DFS. However, when adjusted for stage III substages, probably because of small numbers, only a trend toward statistical significance was observed.

S-100B is located in the cytoplasm of melanoma cells. Elevated serum S100-B occurs as the result of loss of melanoma cell integrity. ${ }^{19}$ Therefore, the hypothesis that elevation of S-100B should be interpreted as a process of subclinical microscopic metastatic disease seems to be suggested by these data. Preoperative elevated S-100B could be an expression of early dissemination not detected by standard imaging tests. ${ }^{33}$ However, the tumor marker is not suitable for screening purposes or for the early detection of recurrence in the follow-up of melanoma patients. ${ }^{34}$

The prognostic biochemical marker S-100B may be of value in the design of future trials on adjuvant systemic chemotherapy or immunotherapy. At present, LDH is the most prominent serum parameter in stage IV melanoma, and it has been included in the new AJCC staging system. ${ }^{5}$ Our study on optimally staged clinical stage III melanoma patients has now shown that preoperative S-100B elevation is associated with significantly poorer survival. These results are supported by studies from M.D. Anderson Cancer Center, Barcelona, and a recent meta-analysis and a pooled analysis of ECOG studies in high-risk surgically resected melanoma by Kirkwood. ${ }^{33,35-37}$ These studies showed that direct postoperative (baseline) $\mathrm{S}-100 \mathrm{~B}$ is indeed a prognostic marker for disease-free survival (DFS) and overall survival (OS). Our results seem in accordance with these data, but more importantly reveal that S-100B is a prognostic marker for DFS when determined before dissection. In our study, the 2-year DFS is slightly better than in the recently published ECOG, which is explained by the fact that the patients were staged with FDG-PET and spiral $\mathrm{CT} .{ }^{37}$ A more refined individualized risk assessment for adjuvant treatment is possible with serum marker S100B. Therefore, S-100B could be included in future stratification research for stage III melanoma.

In summary, preoperative elevation of S-100B levels in patients with true (clinical) stage III melanoma is associated with decreased disease-free survival and might have a prognostic clinical value in high-risk stage III melanoma patients. Therefore S-100B could be used to select patients for adjuvant systematic treatment in the stratification for new adjuvant therapeutic trials as well as to provide information for stage III melanoma patients who want to be informed about disease prognosis.

OPEN ACCESS This article is distributed under the terms of the Creative Commons Attribution Noncommercial License which permits any noncommercial use, distribution, and reproduction in any medium, provided the original author(s) and source are credited.

\section{REFERENCES}

1. Siesling S, Visser O, van Dijck JA, Coebergh JW. Trends in the incidence and death from cancer from 1989-2003 in The Netherlands. Ned Tijdschr Geneeskd. 2006;150:2490-6.

2. Garbe C, Eigentler TK. Diagnosis and treatment of cutaneous melanoma: state of the art 2006. Melanoma Res. 2007;17:117-27.

3. Francken AB, Bastiaannet E, Hoekstra HJ. Follow-up in patients with localised primary cutaneous melanoma. Lancet Oncol. 2005;6:608-21.

4. Morton DL, Thompson JF, Cochran AJ, Mozzillo N, Elashoff R, Essner R, et al. Sentinel-node biopsy or nodal observation in melanoma. N Engl J Med. 2006;355:1307-17.

5. Balch CM, Soong SJ, Gershenwald JE, Thompson JF, Reintgen DS, Cascinelli N, et al. Prognostic factors analysis of 17,600 melanoma patients. Validation of the American Joint Committee on Cancer melanoma system. J Clin Oncol. 2001;19: 3622-34.

6. Bastiaannet E, Oyen WJ, Meijer S, Hoekstra OS, Wobbes T, Jager PL, et al. Impact of $18 \mathrm{~F}$ fluorodeoxyglucose positron emission tomography on surgical management of melanoma patients. Br J Surg. 2006;93:243-9.

7. Bastiaannet E, Wobbes T, Hoekstra OS, van der Jagt EJ, Brouwers AH, Koelemij R, et al. Prospective comparison of FDG-PET and CT in 251 melanoma patients with palpable lymph node metastases; diagnostic accuracy and impact on treatment. $J$ Clin Oncol. (in press).

8. Bastiaannet E, Hoekstra OS, Oyen WJ, Jager PL, Wobbes T, Hoekstra HJ. Level of fluorodeoxyglucose uptake predicts risk for recurrence in melanoma patients presenting with lymph node metastases. Ann Surg Oncol. 2006;13:919-26.

9. Brochez L, Naeyaert JM. Serological markers for melanoma. $\mathrm{Br} J$ Dermatol. 2000;143:256-68.

10. Finck SJ, Giuliano AE, Morton DL. LDH and melanoma. Cancer. 1983;51:840-3. 
11. Karakousis CP, Balch CM, Urist MM, Ross MM, Smith TJ, Bartolucci AA. Local recurrence in malignant melanoma: longterm results of the multiinstitutional randomized surgical trial. Ann Surg Oncol. 1996;3:446-52.

12. Sirott MN, Bajorin DF, Wong GY, Tao Y, Chapman PB, Templeton MA, et al. Prognostic factors in patients with metastatic malignant melanoma. A multivariate analysis. Cancer. 1993; 72:3091-8

13. Fagnart OC, Sindic CJ, Laterre C. Particle counting immunoassay of S100 protein in serum. Possible relevance in tumors and ischemic disorders of the central nervous system. Clin Chem. 1988;34:1387-91.

14. Guo HB, Stoffel-Wagner B, Bierwirth T, Mezger J, Klingmüller D. Clinical significance of serum S100 in metastatic malignant melanoma. Eur J Cancer. 1995;31A:924-8.

15. Smit LH, Korse CM, Hart AA, Bonfrer JM, Haanen JB, Kerst JM, et al. Normal values of serum S-100B predict prolonged survival for stage IV melanoma patients. Eur J Cancer. 2005;41:386-92.

16. Jackel A, Deichmann M, Waldmann V, Bock M, Näher H. S-100 beta protein in serum, a tumor marker in malignant melanomacurrent state of knowledge and clinical experience. Hautarzt. 1999;50:250-6.

17. Bastiaannet E, Beukema JC, Hoekstra HJ. Radiation therapy following lymph node dissection in melanoma patients: treatment, outcome and complications. Cancer Treat Rev. 2005; $31: 18-26$.

18. Henderson MA, Burmeister B, Thompson JF, Di Iulio J,Fisher R, Hong A, et al. Adjuvant radiotherapy and regional lymph node field control in melanoma patients after lymphadenectomy: Results of an intergroup randomized trial. 2009 ASCO Annual meeting, J Clin Oncol. 2009;27 Supplement: Abstract No. LBA9084.

19. Ghanem G, Loir B, Morandini R, Sales F, Lienard D, Eggermont $\mathrm{A}$, et al. On the release and half life of S100B protein in the peripheral blood of melanoma patients. Int J Cancer. 2001; 94:586-90.

20. Martenson ED, Hansson LO, Nilsson B, von Schoultz E, Månsson Brahme E, Ringborg U, et al. Serum S-100b protein as a prognostic marker in malignant cutaneous melanoma. $J$ Clin Oncol. 2001;19:824-31.

21. Mohammed MQ, Abraha HD, Sherwood RA, MacRae K, Retsas S. Serum S100beta protein as a marker of disease activity in patients with malignant melanoma. Med Oncol. 2001;18:109-20.

22. Curry BJ, Farrelly M, Hersey P. Evaluation of S-100beta assays for the prediction of recurrence and prognosis in patients with AJCC stage I-III melanoma. Melanoma Res. 1999;9:557-67.

23. Bonfrer JM, Korse CM, Nieweg OE, Rankin EM. The luminescence immunoassay S-100: a sensitive test to measure circulating S-100B: its prognostic value in malignant melanoma. Br J Cancer. 1998;77:2210-4.

24. Buer J, Probst M, Franzke A, Duensing S, Haindl J, Volkenandt $\mathrm{M}$, et al. Elevated serum levels of S100 and survival in metastatic malignant melanoma. Br J Cancer. 1997;75:1373-6.

25. Hansson LO, von SE, Djureen E, Hansson J, Nilsson B, Ringborg U. Prognostic value of serum analyses of S-100 protein beta in malignant melanoma. Anticancer Res. 1997;17:3071-3.

26. Bonfrer JM, Korse CM, Israels SP. Serum S-100 has prognostic significance in malignant melanoma. Anticancer Res. 1997; 17:2975-7.

27. Hamberg AP, Korse CM, Bonfrer JM, de Gast GC. Serum S100B is suitable for prediction and monitoring of response to chemoimmunotherapy in metastatic malignant melanoma. Melanoma Res. 2003;13:45-9.

28. Hauschild A, Engel G, Brenner W, Gläser R, Mönig H, Henze E, et al. Predictive value of serum S100B for monitoring patients with metastatic melanoma during chemotherapy and/or immunotherapy. Br J Dermatol. 1999;140:1065-71.

29. Henze G, Dummer R, Joller-Jemelka HI, Böni R, Burg G. Serum S100 - a marker for disease monitoring in metastatic melanoma. Dermatology. 1997;194:208-12.

30. Banfalvi T, Boldizsar M, Gergye M, Gilde K, Kremmer T, Otto S. Comparison of prognostic significance of serum 5-S-Cysteinyldopa, LDH and S-100B protein in Stage III-IV malignant melanoma. Pathol Oncol Res. 2002;8:183-7.

31. Banfalvi T, Gilde K, Gergye M, Boldizsar M, Kremmer T, Otto S. Use of serum 5-S-CD and S-100B protein levels to monitor the clinical course of malignant melanoma. Eur J Cancer. 2003; 39:164-9.

32. Garbe C, Leiter U, Ellwanger U, Blaheta HJ, Meier F, Rassner G, et al. Diagnostic value and prognostic significance of protein S100beta, melanoma-inhibitory activity, and tyrosinase/MART-1 reverse transcription-polymerase chain reaction in the follow-up of high-risk melanoma patients. Cancer. 2003;97:1737-45.

33. Domingo-Domenech J, Castel T, Auge JM, Garcia-Albeniz XA, Conill C, Puig S, et al. Prognostic implications of protein S100beta serum levels in the clinical outcome of high-risk melanoma patients. Tumour Biol. 2007;28:264-72.

34. Smit LH, Nieweg OE, Korse CM, Bonfrer JM, Kroon BB. Significance of serum S-100B in melanoma patients before and after sentinel node biopsy. J Surg Oncol. 2005;90:66-9.

35. Chun YS, Wang Y, Wang, DY, McClain DM, Lucci A, Mansfield PF, et al. S100B levels are more accurate than LDH levels at predicting survival in melanoma patients. Ann Surg Oncol. 2008;15:96 (P211).

36. Mocellin S, Zavagno G, Nitti D. The prognostic value of serum S100B in patients with cutaneous melanoma: A meta-analysis. Int J Cancer. 2008;123:2370-6.

37. Tarhini AA, Stuckert J, Lee S, Sander C, Kirkwood JM. Prognostic significance of serum S100B surgically resected melanoma Patients Participating in Intergroup Trial ECOG 1694. J Clin Oncol. 2009;27:38-44.

38. Miliotes G, Lyman GH, Cruse CW, Puleo C, Albertini PA, Rapaport D, et al. Evaluation of new putative tumor markers for melanoma. Ann Surg Oncol. 1996;3:558-63.

39. Abraha HD, Fuller LC, Du Vivier AW, Higgins EM, Sherwood RA. Serum S-100 protein: a potentially useful prognostic marker in cutaneous melanoma. Br J Dermatol. 1997;137:381-5.

40. Bosserhoff AK, Kaufmann M, Kaluza B, Bartke I, Zirngibl H, Hein R, et al. Melanoma-inhibiting activity, a novel serum marker for progression of malignant melanoma. Cancer Res. 1997;57:3149-53.

41. Tofani A, Cioffi RP, Sciuto R, Rea S, Festa A, Di Filippo F, et al. S-100 and NSE as serum markers in melanoma. Acta Oncol. 1997;36:761-4.

42. Schultz ES, Diepgen TL, Von Den DP. Clinical and prognostic relevance of serum S-100 beta protein in malignant melanoma. $\mathrm{Br}$ J Dermatol. 1998;138:426-30.

43. Bonfrer JM, Korse CM. Monitoring malignant melanoma with the S-100B tumour marker. Recent Results Cancer Res. 2001;158:149-57.

44. Seregni E, Massaron S, Martinetti A, Illeni MT, Rovini D, Belli $\mathrm{F}$, et al. S100 protein serum levels in cutaneous malignant melanoma. Oncol Rep. 1998;5:601-4.

45. Hauschild A, Engel G, Brenner W, Gläser R, Mönig H, Henze E, et al. S100B protein detection in serum is a significant prognostic factor in metastatic melanoma. Oncology. 1999;56:338-44.

46. Berking C, Schlupen EM, Schrader A, Atzpodien J, Volkenandt M. Tumor markers in peripheral blood of patients with malignant melanoma: multimarker RT-PCR versus a luminoimmunometric assay for S-100. Arch Dermatol Res. 1999;291:479-84. 
47. Kaskel P, Berking C, Sander S, Volkenandt M, Peter RU, Krähn G. S-100 protein in peripheral blood: a marker for melanoma metastases: a prospective 2-center study of 570 patients with melanoma. J Am Acad Dermatol. 1999;41:962-9.

48. Brouard M, Quillien V, Ollivier I, Lesimple T, Adamski H, Chevrant-Breton J. Serum S100B protein and stage of cutaneous melanoma: a prospective study. Ann Dermatol Venereol. 2000;127:56-9.

49. Vuoristo MS, Kellokumpu-Lehtinen P, Laine S, Parvinen LM, Hahka-Kemppinen M, Korpela M, et al. The value of serum S100beta and interleukins as tumour markers in advanced melanoma. Melanoma Res. 2000;10:237-41.

50. Jury CS, McAllister EJ, MacKie RM. Rising levels of serum S100 protein precede other evidence of disease progression in patients with malignant melanoma. Br J Dermatol. 2000; 143:269-74.

51. Juergensen A, Holzapfel U, Hein R, Stolz W, Buettner R, Bosserhoff A. Comparison of two prognostic markers for malignant melanoma: MIA and S100 beta. Tumour Biol. 2001; 22:54-8.
52. Rebmann V, Ugurel S, Tilgen W, Reinhold U, Grosse-Wilde H. Soluble HLA-DR is a potent predictive indicator of disease progression in serum from early-stage melanoma patients. Int $J$ Cancer. 2002;100:580-5.

53. Andres R, Mayordomo JI, Zaballos P, Rodino J, Isla D, Escudero $\mathrm{P}$, et al. Prognostic value of serum S-100B in malignant melanoma. Tumori. 2004;90:607-10.

54. Ugurel S. Serum markers for melanoma. Hautarzt. 2005;56: 173-84.

55. Schmidt H, Sorensen BS, Fode K, Nexo E, von der Maase H. Tyrosinase messenger RNA in peripheral blood is related to poor survival in patients with metastatic melanoma following interleukin-2-based immunotherapy. Melanoma Res. 2005;15:409-16.

56. Cao MG, Auge JM, Molina R, Marti R, Carrera C, Castel T, et al. Melanoma inhibiting activity protein (MIA), beta-2 microglobulin and lactate dehydrogenase (LDH) in metastatic melanoma. Anticancer Res. 2007;27:595-9. 